Original Paper http://ajol.info/index.php/ijbcs http://indexmedicus.afro.who.int

\title{
Some ecological aspects of the gecarcinid land crab, Cardisoma armatum Herklots, 1851 (Crustacea, Brachyura, Gecarcinidae) from the estuarine region of the Comoe River, Côte d'Ivoire
}

\author{
Olivier Assoi ETCHIAN ${ }^{1 *}$, Richard DAKOURI ${ }^{1}$, Célestin Mélécony BLE ${ }^{2}$, \\ Aderonke Omolara LAWAL-ARE ${ }^{3}$ and José Antonio CUESTA ${ }^{4}$ \\ ${ }^{1}$ Laboratoire de Biologie et Cytologie Animales, UFR-SN, Université Nangui Abrogoua (ex-Université \\ d'Abobo-Adjamé), 02 BP 801 Abidjan 02, Côte d'Ivoire. \\ ${ }^{2}$ Centre de Recherches Océanologiques, Département Aquaculture, BP V 18 Abidjan, Côte d'Ivoire. \\ ${ }^{3}$ Department of Marine Sciences, University of Lagos, Akoka, Lagos 234, Nigeria. \\ ${ }^{4}$ Institute of Marine Sciences of Andalusia (CSIC), Campus Rio San Pedro, 11510 Puerto Real, (Cádiz), Spain. \\ *Corresponding author; E-mail: oetchian@yahoo.ca ; etchianass_sn@una.edu.ci
}

\section{ACKNOWLEDGEMENTS}

The work was partially funded by the Ministère de l'Enseignement Supérieur et de la Recherche Scientifique de la Cote d'Ivoire.

\begin{abstract}
Cardisoma armatum Herklots, 1851 is a land crab endemic to tropical coastal ecosystems and represents an important fishery resource. C. armatum was collected using traps at the eastern region of the Ebrie lagoon and the estuarine region of the Comoé River in 2009 during the high rainy season extending from mid-May to mid-July and in low dry season from mid-July to September. Some biometric parameters are measured to determine some aspects of population structure and condition of this edible crab. Sexual dimorphism was confirmed with the major chelae of male crabs reaching larger sizes than those of females. The sex ratio that varied with the sampling periods was associated with migrations occurring during the breeding season. Positive, negative, and positive allometric growth patterns were observed for the carapace length-total weight relationship, respectively, in males, females, and the population as a whole. For the carapace width/total weight relationship, negative allometric growth was observed, respectively, in males, females, and the whole population. Our data show an evidence of a serious problem of recruitment in the population of this crab related to degradation of the habitats and heavy harvesting pressures, highlighting the necessity of developing and implanting management and protection strategies of this crustacean.
\end{abstract}

(C) 2016 International Formulae Group. All rights reserved.

Keywords: Cardisoma armatum, Population structure, Condition index, Ebrie lagoon, Comoé River, Côte d'Ivoire. 


\section{INTRODUCTION}

Crabs of the family Gecarcinidae, Macleay, 1838 (Brachyura, Grapsoidea) are often large in size and commonly referred to as 'land crabs' (or 'land-dwelling' crabs), based on the terrestrial habits shown by adults of most species belonging to this family (Cuesta et al., 2002). Indeed, the gecarcinid crabs are able to survive kilometers from the coasts (Gilchrist, 1988; Burggren and McMahon, 1988), but they must return to marine waters to release their larvae (Hostetler et al., 1991; Cuesta and Anger, 2005). After a period in the plankton, they return to the mainland as megalops or first crab stages (Wolcott, 1988). The costal environments with different type of vegetation and soils are the preferred habitats of the gecarcinid crabs (López-Victoria and Werding, 2008), where they live in burrows several feet deep at least to a level that will allow water to seep in for moisture (Evoy and Fourtner, 1973). The gecarcinid crabs are primarily vegetarians preferring tender leaves, fruits, berries, flowers and beetles or other large insects occasionally, showing that they have an omnivorous diet. Currently, the family Gecarcinidae comprises 19 species of crabs that are distributed among six genera, including Cardisoma Latreille, 1825 (Manning and Holthuis, 1981).

The gecarcinid land crab Cardisoma armatum Herklots, 1851 is a tropical species known from the Cape Verde Islands and from Senegal to Angola, including Fernando Poo and SaoTome islands in the Gulf of Guinea (Manning and Holthuis, 1981). This crab forms an important part of the diets of coastal and riverine communities (Omotoso, 2005; Elegbede and Fashina-Bombata, 2013). C. armatum is found in Côte d'Ivoire (d'Almeida et al., 2014) where the fishing of this species of commercial interest is experiencing an intense activity (FAO, 2004). Biometric studies are well known to be useful for a management of sustainable fisheries (Anetekhai et al., 1994; Akin-Oriola et al.,
2005). This study was undertaken to provide some aspects on the general biology, population structure, condition and ecological interactions of $C$. armatum at the estuarine region of Comoe River with the Ebrie lagoon.

\section{MATERIALS AND METHODS}

\section{Description of study area and crabs collection}

The study area is located in GrandBassam at the eastern end of the Ebrie lagoon and the estuarine region of the Comoé River and facing to the Atlantic Ocean in the south at about $2 \mathrm{~km}$ (Figure 1). The region of the study has a wet equatorial climate characterized by two rainy seasons and two dry seasons (Koné et al., 2009). The Comoé River estuary falls within Latitudes $5^{\circ} 12^{\prime}$ and $5^{\circ} 14^{\prime}$ north and Longitudes $3^{\circ} 42^{\prime}$ and $3^{\circ} 44^{\prime}$ west of the Greenwich Meridian (Adopo et al., 2008; Adopo and Romanescu, 2013). This part of the Ebrie lagoon is characterized by heavy rainfall and inputs from terrestrial runoff, with water temperature reaching its yearly minimum value (Durand and Guiral, 1994).

The crabs collected on land comprise the two Moossou bridges using traps (for review, see Emmanuel, 2009) with the assistance of artisanal fishermen. Here, mangroves, plantations of palm oil, sugar cane and rice covered the land. During our investigations, the traps were baited with unripe papaya, palm kernels, dry almond coconut, cassava, pineapple peels and mainly with sugar cane for its availability and low cost. The individuals were collected in the high rainy season extending from mid-May to mid-July and in low dry season from mid-July to September. At each sampling period, 20 crabs were collected. These were preserved in a cool box and rapidly transferred to the Oceanologic Research Center (CRO) located in Abidjan for analyses.

\section{Measurement of parameters}

In the laboratory, the identification of the sex in Cardisoma armatum specimens was 
carried out using an illustrated guide (Schneider, 1992). The body wet weight (WW) of the crabs was measured using a balance (Mettler PJ 6) $6 \mathrm{~kg}$ scope with a precision of 0.01 . The following body dimensions were measured with a vernier caliper to the nearest $0.05 \mathrm{~mm}$ : carapace length (CL), carapace width $(\mathrm{CW})$, the height of the major chela (HMC) and abdomen length (AL). Growth ratios for the dependent variable (WW) and the independent variables (CL and $\mathrm{CW}$ ) were recorded by using the power function $\mathrm{Y}=\mathrm{aX}$, where $\mathrm{x}$ is the independent variable $(\mathrm{CW}), \mathrm{Y}$ is the dependent variable, "a" is the intercept of the regression curve and $b$ the regression coefficient. The "b" value represents the relative growth constant $(\mathrm{b}=3$ means isometric growth; $\mathrm{b}>3$ means positive allometric growth; and $\mathrm{b}<3$ means negative allometric growth) (Abohweyere and Williams, 2008; Abowei and George, 2009). The Fulton's condition factor $(\mathrm{K})$ of the crabs was determined using the formula (Richter et al., 2000; Lawal-Are and Bilewu, 2009):

$\mathrm{K}=100 \mathrm{~W} / \mathrm{L}^{\mathrm{b}} \quad$ where:

$\mathrm{WW}=$ Wet weight of crab $(\mathrm{g})$,

$\mathrm{L}=$ Carapace length in $\mathrm{cm}$,

and the value $\mathrm{b}$ is a constant (regression coefficient) determined from the lengthweight relationship: $\mathrm{W}=\mathrm{a} \times \mathrm{L}^{\mathrm{b}}$

\section{Statistical analyses}

The statistical significance of the " $b$ " for the isometry (Ho: $b=3$ ), sex ratio and dimorphism traits was tested using the Student's $t$-test $(\alpha=0.05)$. To test the effect of sex and sampling period on condition factor (K), a GLM procedure was performed. When a significant effect $(\mathrm{P}<0.05)$ was observed, the post hoc Least Squares Difference (LSD) test was used. Data were processed using the program SAS for personal computer (SAS, 2008).

\section{RESULTS \\ Size distribution}

The data of the carapace length (CL) frequency distribution of crabs are shown in Figure 2. The female population was divided into $3 \mathrm{CL}$ classes with values varying from 3.5 to $6.4 \mathrm{~cm}$ (Figure 2a), whilst for males, $5 \mathrm{CL}$ classes are found with values ranging from 3.5 to $8.4 \mathrm{~cm}$ (Figure 2b). A unimodal $\mathrm{CL}$ distribution is observed in the population (Figure 2c), with the modal CL class of 4.5 $5.4 \mathrm{~cm}$ for each sex. The mean are $5.96 \mathrm{~cm}$ CL for females, and $6.47 \mathrm{~cm} \mathrm{CL}$ for males, the maximum $\mathrm{CL} 7.0 \mathrm{~cm}$ and $9.6 \mathrm{~cm}$, respectively. For carapace width $(\mathrm{CW}), 3 \mathrm{CW}$ classes are listed ranging from 4.5 to $7.4 \mathrm{~cm}$ in female crabs (Figure 3a). For males, $6 \mathrm{CW}$ classes with values varying from 4.5 to 10.4 are provided (Figure 3b). In addition, a unimodal $\mathrm{CW}$ distribution is observed (Figure $3 \mathrm{c})$. The modal $\mathrm{CW}$ class was $5.5-6.4 \mathrm{~cm}$ for each sex. The mean were $4.92 \mathrm{~cm} \mathrm{CW}$ for females, and $5.20 \mathrm{~cm} \mathrm{CW}$ for males, the maximum $\mathrm{CW} 5.9 \mathrm{~cm}$ and $8.3 \mathrm{~cm}$, respectively.

\section{Sex ratio and sexual dimorphism}

Table 1 summarizes sex ratio data for Cardisoma armatum examined during the present study. Sampling period had a significant $(\mathrm{P}<0.05)$ effect on the sex ratio values. The number of male individuals equal to females for crabs caught in May 12 th, June 4 th and July 21 st. On the other hand, sex ratio of crabs in early July and in late July is in favor of the males. Considering all sampling periods together, a statistical difference was evident in the population with an index of 1:0.82 in favour of male crabs. The results of the morphological measures realized in male and female crabs are summarized in Table 2. The body weight (WW) and the major chela height (HMC) in male crabs were higher ( $\mathrm{P}<$ 0.05) than in female individuals. Regarding the other parameters as carapace length (CL), carapace width (CW) and abdomen length 
(AL) measured in the crabs, no significant difference was detected between males and females.

\section{Width/Length-Weight relationships: allometric growth patterns}

The power function used to study the length-weight and width-weight relationships are illustrated in Figure 4 and Figure 5 respectively, and the different parameters obtained are shown in table 3. The relationship between the body weight (WW in $\mathrm{g})$ and the carapace length (CL in $\mathrm{cm}$ ) was expressed as $\mathrm{WW}_{\mathrm{F}}=0.63 \mathrm{CL}_{\mathrm{F}}^{2.80}\left(\mathrm{R}^{2}=0.84\right)$ for female, $\mathrm{WW}_{\mathrm{M}}=0.25 \mathrm{CL}_{\mathrm{M}}^{3.27}\left(\mathrm{R}^{2}=0.93\right)$ for male and $\mathrm{WW}_{\mathrm{P}}=0.3 \mathrm{CL}_{\mathrm{P}}^{3.22}$ for combined sex (total population) (Table 3). The WW vs $\mathrm{CW}$ relationship in female, male and population, the regression equations $\mathrm{WW}_{\mathrm{F}}=$ $1.77 \mathrm{CW}_{\mathrm{F}}^{2.52}\left(\mathrm{R}^{2}=0.83\right), \mathrm{WW}_{\mathrm{M}}=0.92 \mathrm{CW}_{\mathrm{M}}^{2.93}$ $\left(\mathrm{R}^{2}=0.86\right)$, and $\mathrm{WW}_{\mathrm{P}}=0.93 \mathrm{CW}_{\mathrm{P}}^{2.91}\left(\mathrm{R}^{2}=\right.$
$0.86)$ were plotted respectively. A positive (b $>3)$, negative $(\mathrm{b}<3)$ and positive allometric growth patterns were observed for CL/WW relationship in male, female and population, respectively. For CW/WW relationship, a negative allometric growth $(b<3)$ is observed in male, female and population (Table 3).

\section{Changes in condition factor $(K)$}

The condition factor $(\mathrm{K})$ values in each sex and within population are illustrated in Figure 6. Sampling period had a significant $(\mathrm{P}$ $<0.05)$ effect on condition factor. In early May, values were higher in female crabs $(\mathrm{K}=$ $47.00 \pm 6.97)$ than in males $(K=40.33 \pm$ 8.49). In late July, in male crabs (43.38 \pm 3.31 ), this value was slightly higher than in females $(41.47 \pm 0.95)$. For other sampling periods, no statistical difference between the two sexes was observed for the condition factor K (Figure 6).

Table 1: Comparison of sex ratios for C. armatum in each of the sampling periods.

\begin{tabular}{lccccc}
\hline Sampling period & Males & Females & Ratio (M:F) & df & P \\
\hline May 12, 2009 & 9 & 9 & $1: 1$ & 1 & $>0.05$ \\
June 04, 2009 & 10 & 11 & $1: 1.1$ & 1 & $>0.05$ \\
July 06, 2009 & 13 & 8 & $1: 0.62$ & 1 & $<0.05^{*}$ \\
July 21, 2009 & 9 & 10 & $1: 1.11$ & 1 & $>0.05$ \\
July 30, 2009 & 14 & 7 & $1: 0.5$ & 1 & $<0.05^{*}$ \\
All samples & 55 & 45 & $1: 0.82$ & 1 & $<0.05^{*}$ \\
\hline
\end{tabular}

Each value indicates Mean \pm Standard Deviation (Mean \pm S.D). *: Indicates significant difference at $\mathrm{P}<0.05$ between sexes

Table 2: Descriptive statistics for weight and body measurements in C. armatum.

\begin{tabular}{lcc}
\hline Variables & Females & Males \\
\hline WW $(\mathrm{g})$ & $99.71 \pm 24.30$ & $121 \pm 65.62^{*}$ \\
CL $(\mathrm{cm})$ & $6.10 \pm 0.50$ & $6.46 \pm 0.60$ \\
CW $(\mathrm{cm})$ & $4.94 \pm 0.40$ & $5.18 \pm 0.50$ \\
HMC $(\mathrm{cm})$ & $2.53 \pm 0.30$ & $3.04 \pm 0.40^{*}$ \\
AL $(\mathrm{cm})$ & $3.52 \pm 0.40$ & $3.84 \pm 1.14$
\end{tabular}

Each value indicates Mean \pm Standard Deviation (Mean \pm S.D). $\mathrm{WW}=$ wet weight, $\mathrm{CL}=$ carapace length, $\mathrm{CW}=$ carapace width; $\mathrm{HMC}=$ Height of the major chela, $\mathrm{AL}=$ Abdomen length. $*$ : Indicates significant difference at $\mathrm{p}<0.05$ between sexes. 
Table 3: Size-weight relationship $\left(\mathrm{W}=\mathrm{aL}^{\mathrm{b}}\right)$ parameters for $C$. armatum

\begin{tabular}{|c|c|c|c|c|c|c|c|c|c|}
\hline \multirow[b]{2}{*}{ Variables } & \multicolumn{3}{|c|}{ Females } & \multicolumn{3}{|c|}{ Males } & \multicolumn{3}{|c|}{ Population } \\
\hline & $\mathbf{N}$ & $\left(Y=a X^{2}\right)$ & $\mathbf{R}^{2}$ & $\mathbf{N}$ & $\left(Y=a X^{\natural}\right)$ & $\mathbf{R}^{2}$ & $\mathbf{N}$ & $\left(Y=a X^{2}\right)$ & $\mathbf{R}^{2}$ \\
\hline $\mathrm{WW}-\mathrm{CL}$ & 45 & $\mathrm{WW}_{\mathrm{F}}=0.63 \mathrm{CL}_{\mathrm{F}}^{2.80}$ & 0.84 & 55 & $\mathrm{WW}_{\mathrm{M}}=0.25 \mathrm{CL} \mathrm{M}^{3.27}$ & 0.930 & 100 & $\mathrm{WW}_{\mathrm{P}}=0.3 \mathrm{Cl}_{\mathrm{P}}^{3.22}$ & 0.92 \\
\hline \multicolumn{2}{|c|}{ WW - CW 45} & $\mathrm{WW}_{\mathrm{F}}=1.77 \mathrm{CW}_{F}^{2.52}$ & 0.83 & 55 & $\mathrm{WW}_{\mathrm{M}}=0.92 \mathrm{CW}_{\mathrm{M}}^{2.93}$ & 0.86 & 100 & $\mathrm{WW}_{\mathrm{P}}=0.93 \mathrm{CW}_{\mathrm{P}}^{2.91}$ & 0.86 \\
\hline
\end{tabular}

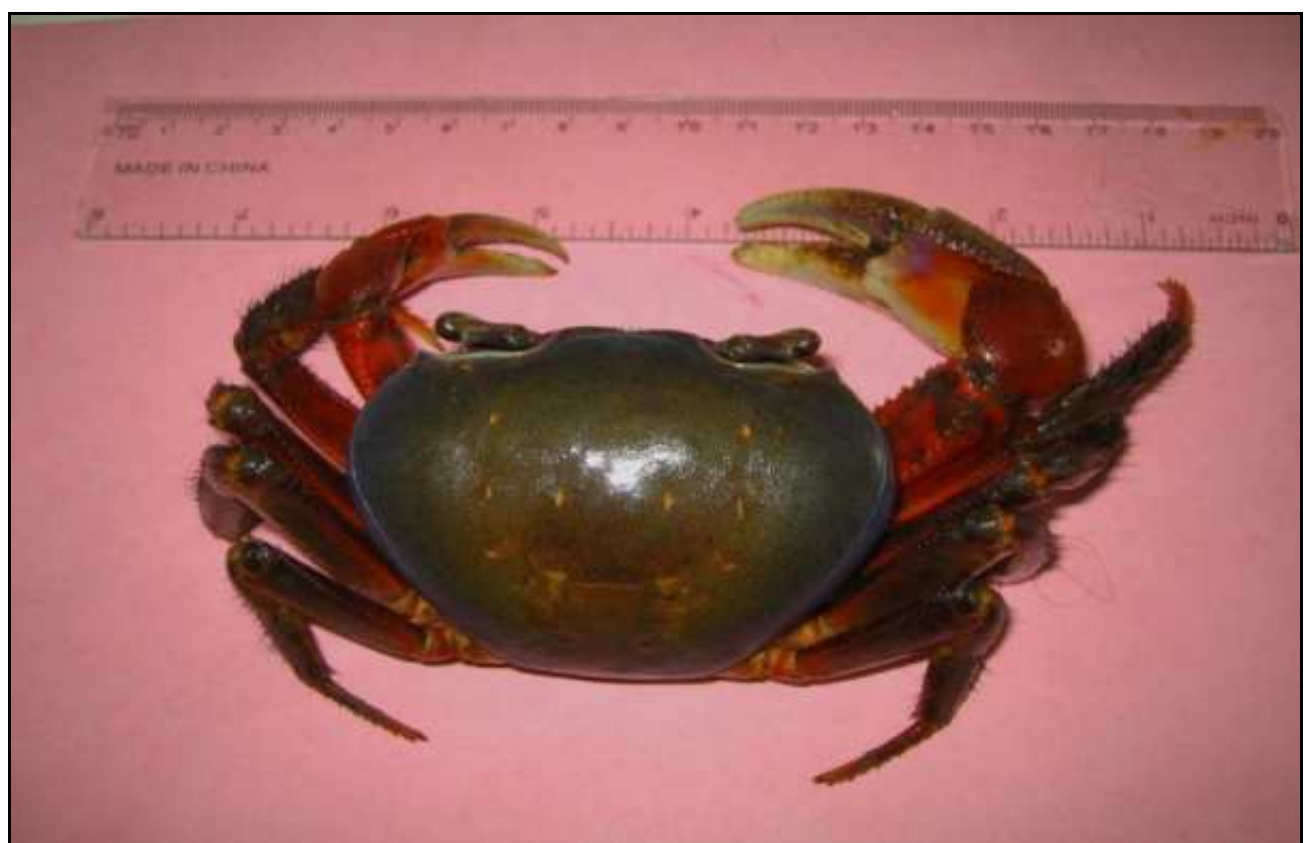

Plate 1: A dorsal view of a Cardisoma sp. Herklots 1851. 




Plate 2: A ventral view of a mature female of Cardisoma sp. Herklots 1851.

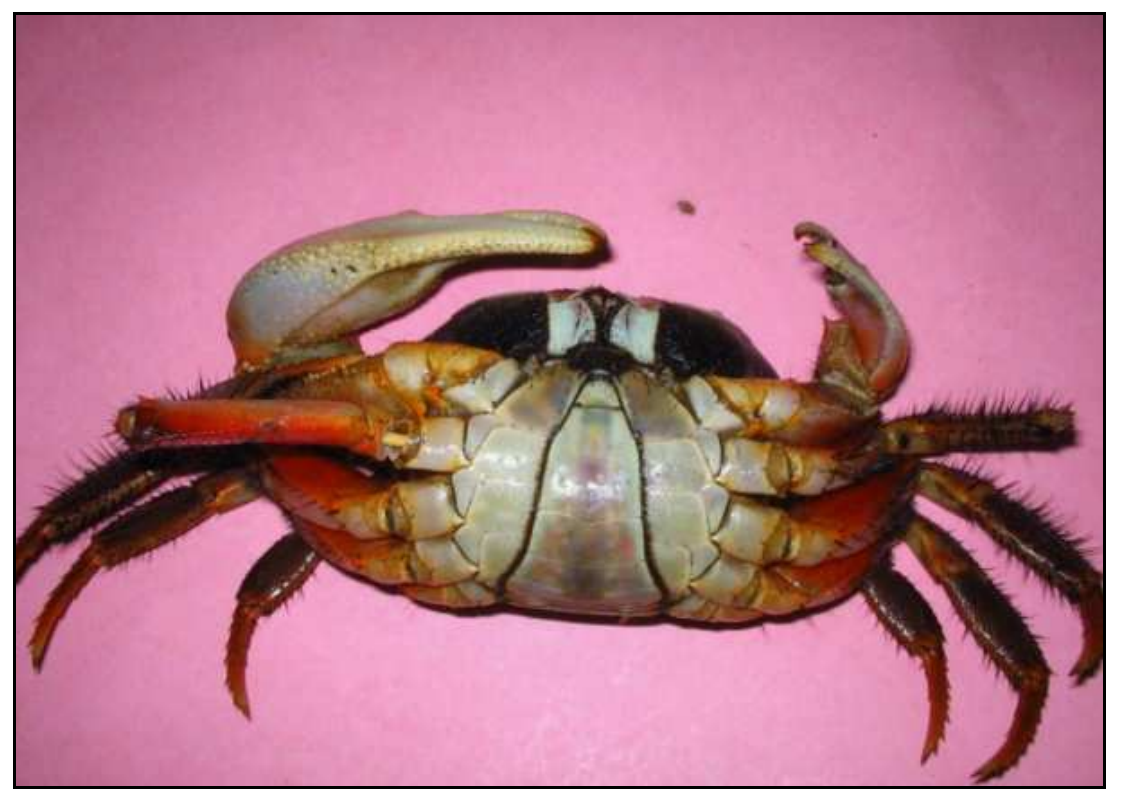

Plate 3: A ventral view of a mature male of Cardisoma sp. Herklots 1851. 
O. A. ETCHIAN et al. / Int. J. Biol. Chem. Sci. 10(2): 457-474, 2016

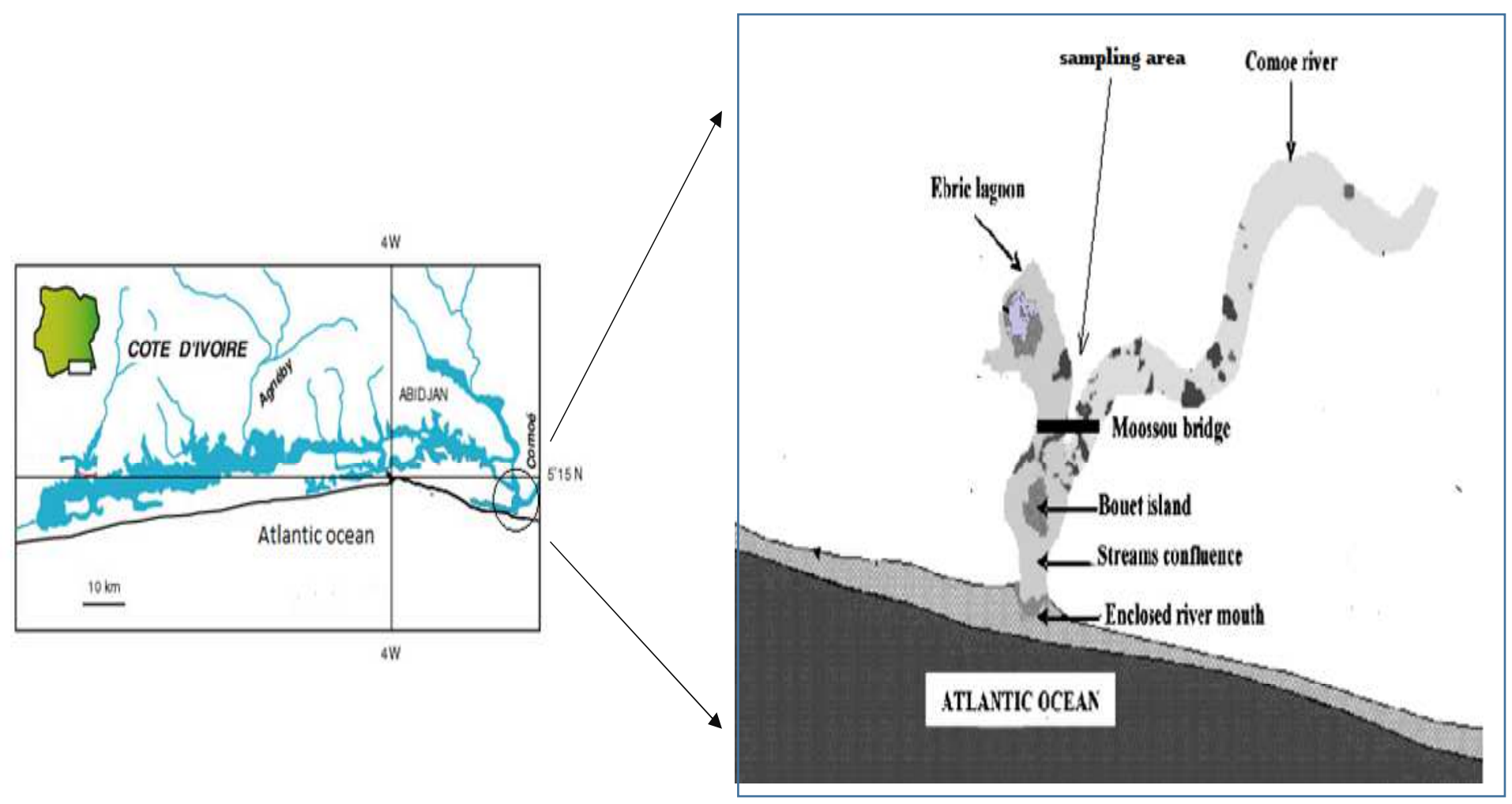

Figure 1: Geographical relative situation of the study site (modified from Adopo et al., 2008). 

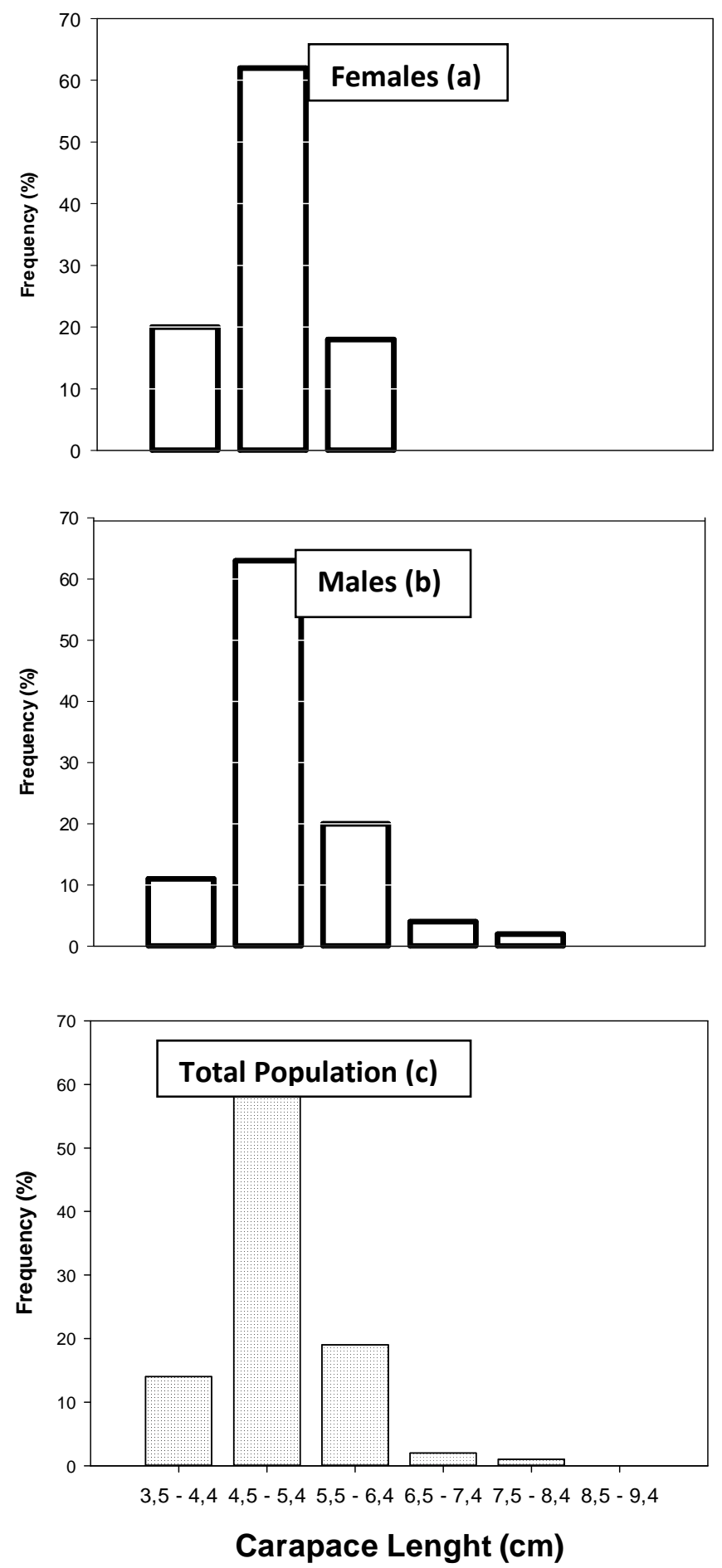

Figure 2: Frequency distribution of C. armatum in females (a), males (b) and total population (c). 

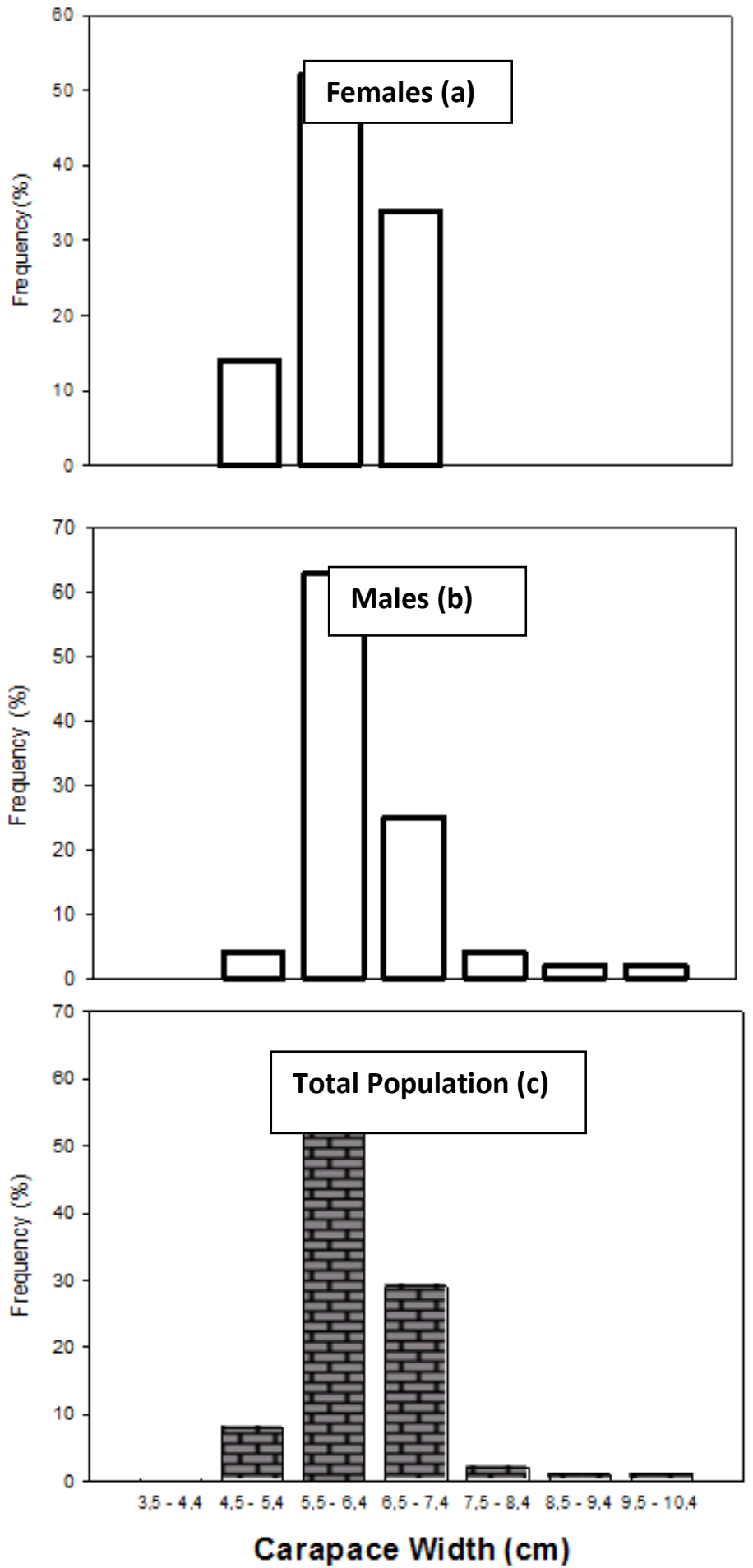

Figure 3: Frequency distribution of C. armatum in females (a), males (b) and population (c). 
O. A. ETCHIAN et al. / Int. J. Biol. Chem. Sci. 10(2): 457-474, 2016
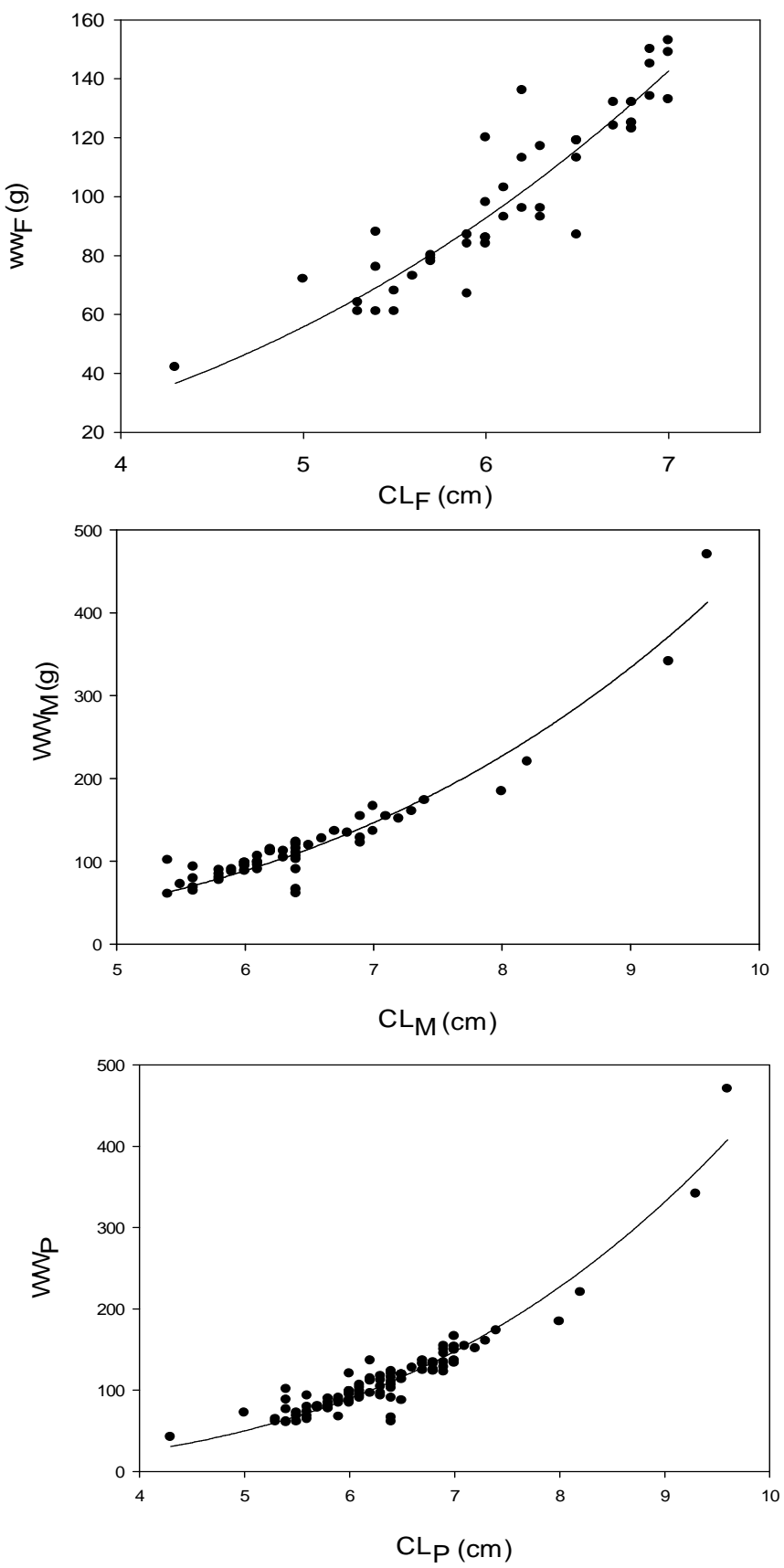

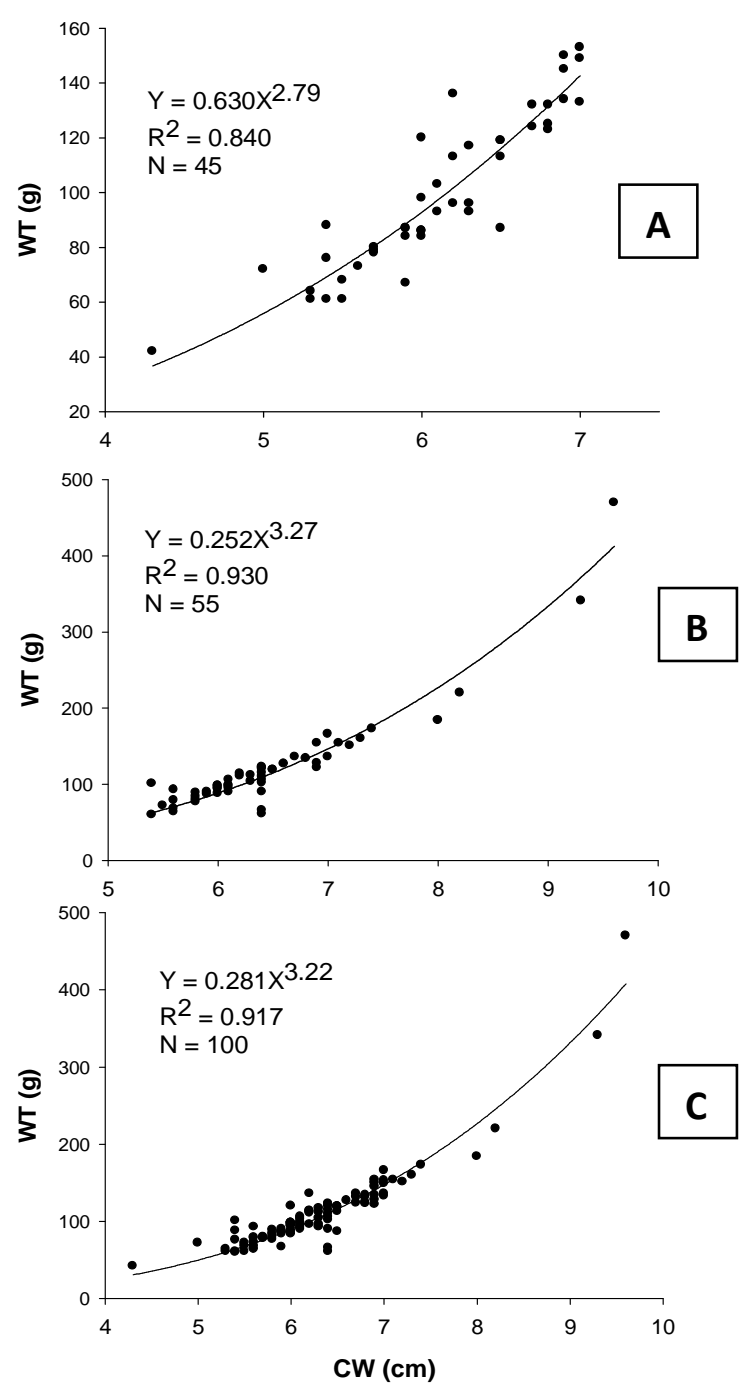

Figure 4: Scattered diagrams of the Length- weight relationship in females (A), males (B) and population $(\mathrm{C})$ of $C$. armatum. $\mathrm{WW}=$ wet weight $(\mathrm{g}) ; \mathrm{CL}=$ carapace length $(\mathrm{cm}) ; \mathrm{CW}=$ carapace width; $\mathrm{WW}=\mathrm{aCL}^{\mathrm{b}}$ represents the power function of the regression analysis. 

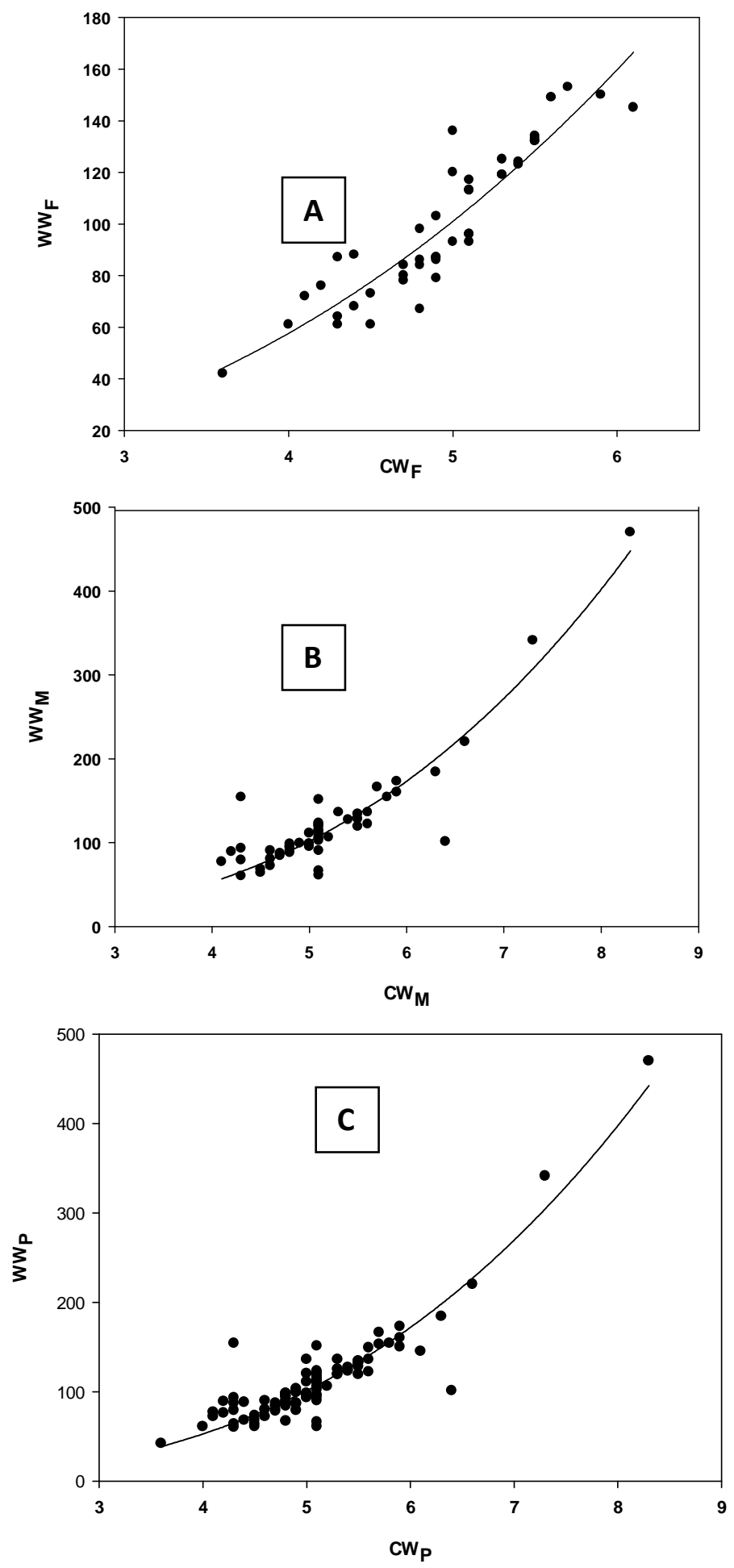

Figure 5: Graphs of dispersion of points and the power function fitted to the empirical points of the WW/CW relationship for females (A), males (B) and population (C) in C. armatum. WW = wet weight; $\mathrm{CW}=$ carapace width; $\mathrm{WW}=\mathrm{aCW}^{\mathrm{b}}$ represents the power function of the regression analysis. 


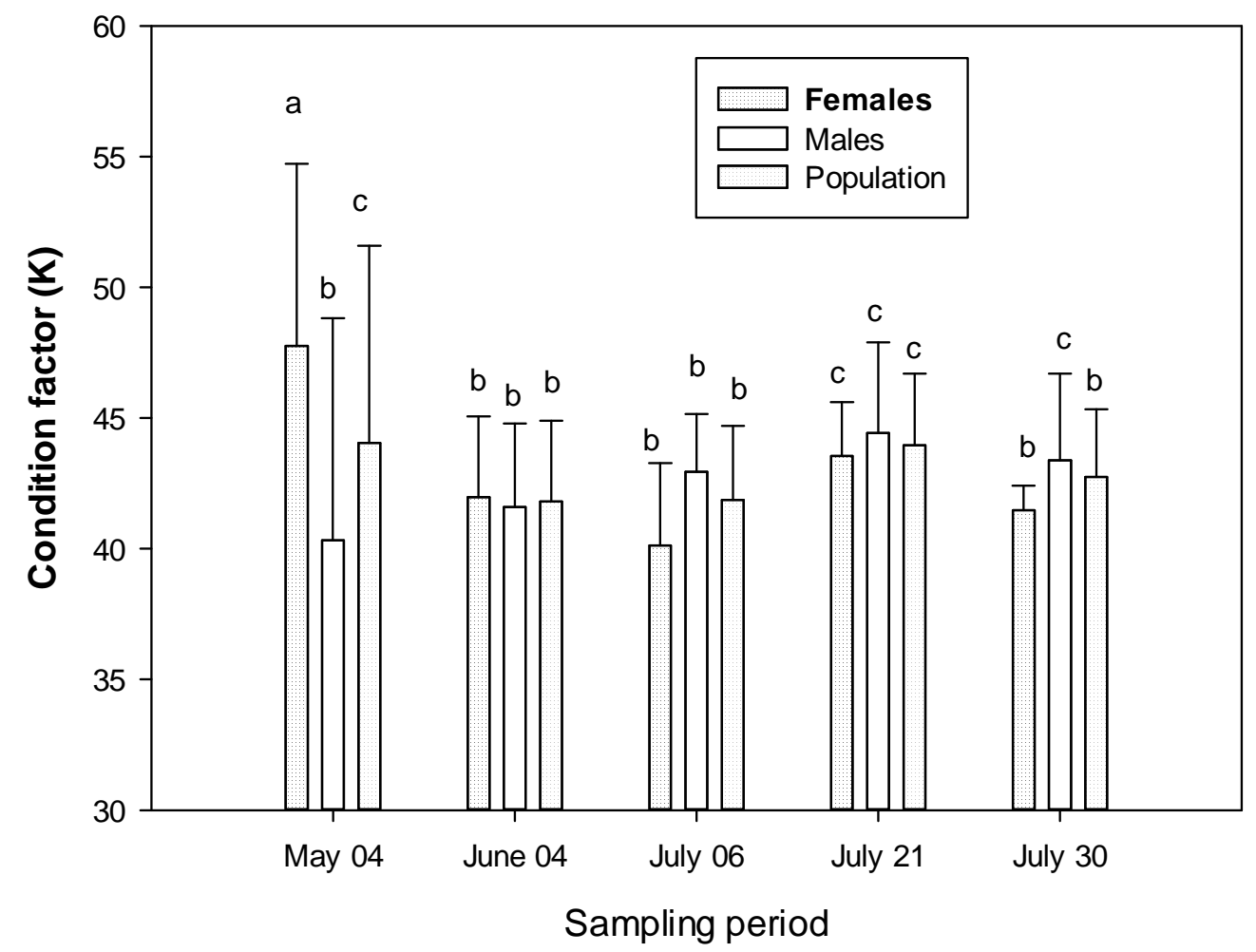

Figure 6: Variations in condition factor $(\mathrm{K})$ of $C$. armatum during sampling period (each value indicates mean \pm standard deviation, $\mathrm{SD})$. The $\mathrm{K}$ values were calculated using carapace length $(\mathrm{cm})$.

\section{DISCUSSION}

The sexual dimorphism is confirmed with the major chelae of male Cardisoma armatum reaching larger sizes than females. Indeed, crabs are well known to exhibit heterochely, a phenomenon characterized by one claw larger than other, with the major chela occurring on the right or left side with variable frequencies. It occurs in a wide range of decapods, but is particularly well developed in some of the land crabs, notably the genera Uca (Valiela et al., 1974) and Cardisoma (Burggren and McMahon, 1988). The heterochely in $C$. armatum is resulted in a slight tendency towards left-handedness (53\%) although in Callinecte spallidus De Rocheburne 1883 (Akin-Oriola et al., 2005), the tendency was definitely towards righthandedness $(79 \%)$. The significance of heterochely in crabs is unclear (Daniels, 2001), but this phenomenon limited to male crabs is currently associated with sexual signalling, combat and obstruction of the borrow entrance (Burggren and McMahon, 1988).

In respect to the body weight of crabs Cardisoma armatum recorded, our data indicate that males are heavier than females, while in another work no significant difference between the two sexes was noted (Akin-Ariola et al., 2005).We believe that factors such as age and the stage of sexual maturation could be responsible for this situation. Regarding of the sex ratio, the analysis of data showed that the sampling periods have affected this one, showing a seasonal variation in the number of male and female individuals caught during the year. The number of males equal to females in May 12th, June 4th and 21 of July. In contrast, many males were caught in early July (July 6th) and more again in late July (July 30th) 
with sex ratios corresponding to 1:0.62 and 1:0.5 respectively. Thus, this difference in sex ratio in favor of the male individuals could be attributed to the fact that an elevated proportion of female crabs that migrated to the shore for breeding season. Indeed, crabs used in our study were caught during rainy season and most of them during full moons. This observation is confirmed by the young men who practice crab trapping in the area. They indicated great migrations of these crustaceans to the Atlantic Ocean during that period of the year. According to Foale (1999), the female land crab, Cardisoma carnifex Herbst 1796 released larvae in large quantities 3 days before the full moon and large larval release migrations peaking 2 days after new moon, just after dark. Hartnoll et al. (2009) have calculated the sex ratio in the land crab, Johngarthia lagostoma H. Milne Edwards, 1837 categorized as resident, migrating and breeding season during the period of the seaward breeding migrations. They found that the breeding population on the shore was heavily dominated by females, while the population in the 'residential' areas, where crabs occur outside the breeding season, had a surplus of males. It is also possible that movements of crabs to sea fulfill need for osmoregulation (Ameyaw-Akumfi, 1987, 1989; Greenaway, 1989). The migrations to sea for osmoregulation are also in agreement with our results. Our sampling period corresponds to the rainy season. At that time, the area receives huge amounts of freshwater from the Comoé River and those from the land causing a drastic lowering of the salinity of water (Durand and Guiral, 1994). Currently, the mouth of this river is closured (Hauhouot, 2002).This closure prevents the intrusion of marine waters into Comoé River and Ebrie Lagoon, a situation leading to a freshening of waters in the area. Since crabs need marine waters for breeding, they are forced to migrate on long distances to search higher salinities environments. For most land crab species, the migration to the sea involves a measure of risk and stress, since the crabs must leave their refuges and travel considerable distances, involving exposure to predators as man and environmental stress (Hartnoll et al., 2006). Thus, the opening of the mouth of the Comoé River is welcome. It will allow an entry of marine waters in the area and it will be beneficial for crabs, especially during reproductive cycle. Since $C$. armatum has marine larvae, it has to migrate to the sea where the salinity is high for osmoregulation and/or spawning. The osmotic sensitivity of the larval stages forces ovigerous females to migrate to highly saline waters for larvae releasing (Adiyodi, 1988; Cuesta and Anger, 2005).

The size structure data showed a modal carapace length (CL) class of 4.5-5.4 $\mathrm{cm}$ for female and male crabs. With the same species caught in the Ojo Lagoon (Lagos, Nigeria) sampled monthly over 12 months, AkinOriola et al. (2005) listed for the population (male and female crabs) modal CL classes of 3-3.9 cm for July, 5-5.9 cm in March, and 4 $4.9 \mathrm{~cm}$ for other months remaining. We did not catch crabs of either sex having a size less than $3.5 \mathrm{~cm}$, namely individuals belonging to the class CL of $2.5-3.4 \mathrm{~cm}$. This death of small specimens or juveniles in our samples could be explained by the fact that they remain inside the burrows of adults conspecifics as observed for juveniles Cardisoma carnifex (Vannini et al., 2003). Another explanation is that Cardisoma armatum faces problems with the recruitment. Indeed, according to Hartnoll et al. (2009), land crabs show in general irregular recruitment patterns due to the uncertainty of return to land after the planktonic larval phase. Another explanation is that the decrease of $C$. armatum population is due to heavy harvesting pressures and degradation of the habitats of these crustaceans. In our study, the mean of $5.96 \mathrm{~cm}$ CL for females, and 6.47 $\mathrm{cm}$ CL for males, and the maximum CL $7 \mathrm{~cm}$ and $9.6 \mathrm{~cm}$, respectively are listed. In land crabs, Cardisoma guanhumi Lattreille 1825 is the lager member with a maximum size of 13 $\mathrm{cm}$ followed by Johngarthia lagostoma with 
$12 \mathrm{~cm}$ as a maximum size listed (Hartnoll et al., 2009). The larger size reached by male crabs is commonly observed in land crab demography and in many other crab species (Hartnoll, 1982; Hartnoll et al., 2006; Pinheiro and Fiscarelli, 2009). A possible reason for male crabs reaching a larger size is that females expend greater resources for reproduction, at the expense of growth. Specifically in land crabs, females of most species play a greater part in the seaward breeding migrations, being thereby exposed to greater risk and increased mortality. The second explanation is that since larger males have greater changes of obtaining females for copulation and win more intra-specific combats. Finally, a major constraint on growth is the problem of obtaining water for post-moult expansion for most land crabs. Species of Cardisoma are known to be supratidal animals which avoid this constraint by burrowing down to the water table: this will facilitate a larger moult increment, helping them to reach a larger size (Hartnoll et al., 2009). Indeed, the environmental parameters are well known to modulate the growth for many crustaceans (Hartnoll, 2001; Skinner et al., 2007).

The positive allometric growth between the body weight and the carapace length means that the male cardisoma armatum becomes heavier for its length as it increase in size, while a negative allometric growth is observed in female, i.e. this one becomes lighter of its length as it grows. A positive allometric growth is indicated in the mixed population with our present investigation. In the same species, a negative allometric growth was observed for females, but not for male crab and mixed population (Akin-Oriola et al., 2005). Huxley and his colleague are the first to postulate the concept of 'allometry' (Huxley and Tessier, 1936). Thus, many studies have extensively applied allometry to estimate the population growth patterns in fish (Le Cren, 1951; Jones et al., 1999; Aguirre, 2003) and crustaceans (Pinheiro and Fiscarelli, 2009; Coasta and Soares-Gomes, 2008; Mohapatra et al., 2010). Allometric studies are useful to estimate biomass production and essential for modeling works on the structure, animal growth and energy flow in ecosystems (Miyasaka et al., 2007).

The condition factor $(\mathrm{K})$ value calculated in Cardisoma armatum is higher $(47.00 \pm 6.97)$ in females than in males $(40.33$ $\pm 8.49)$ in early May, this index is elevated $(43.38 \pm 3.3)$ in males compared to females $(41.47 \pm 0.95)$ when the sampling of the crabs has been done in late July, and finally, this ecological index has not varied significantly in both sexes for the other samplings remaining. For the same species, $\mathrm{K}$ values were $133.0 \pm 9.22$ in males and $136.3 \pm 7.7$ in females (Akin-Oriola et al., 2005). In the equation linking $\mathrm{K}$ to the length, if the weight remains constant and the length increases, the value of $\mathrm{K}$ will decrease, and then will become small. We have calculated indeed the values of $\mathrm{K}$ with a standard size as the carapace length. Since the width is smaller than the length of carapace, the values of $\mathrm{K}$ listed with the carapace width were similar (data not shown in this study, personal comm.) to those obtained by Akin-Oriola et al. (2005) with the same species. Few studies showed that sex may influence the condition factor $\mathrm{K}$ recorded in crabs (Lawal-Are and Kusemiju, 2000; Abowei and George, 2009). It is interesting to note that the values of $\mathrm{K}$ that changed with sampling periods are in agreement with the seasonal changes in this index already described in several aquatic organisms (Godinho, 1997; Pinheiro and Fiscarelli, 2009; Deekae and Abowei, 2010). Indeed, prior to the spawning season, the $\mathrm{K}$ values increase with length (Thompson, 1942). This index known to be affected by the length is regulated by few endogenous and exogenous parameters like food supply, degree of parasitism, and above all, the sexual cycle (Le Cren, 1951; Rodriguez, 1987).

In summary, the present study has provided the first results on some ecological aspects, more specifically the population structure and condition in the gecarcinid land 
crab, cardisoma armatum from eastern Côte d'Ivoire. Our data will be useful for the sustainable management of fisheries. An evidence of a serious problem of recruitment in the population of $C$. armatum is observed. This situation is known to be associated to degradation of the habitats and heavy harvesting pressures, highlighting the necessity of developing and implanting management and protection strategies of this crustacean. Since this important fishery resource is commonly harvested by vulnerable population, the carcinoculture could be an alternative to reduce the poverty in the population of fishermen and promote biodiversity conservation.

\section{ACKNOWLEDGEMENTS}

The help of Dr. Dagou Seka for its statistical assistance was greatly appreciated.

\section{REFERENCES}

Abohweyere PO, Williams AR. 2008. Length-weight relationship and condition factor of Macrobrachium macrobrachion in the Lagos Lekki lagoon system. Res. J. Biol. Sci., 3: 1333-1336.

Abowei JFN, George ADI. 2009. A study of the length-weight Relationship and Condition Factor of Callinectes amnicola (De Rochebrune, 1883) from Okpoka Creek, Niger Delta, Nigeria. Int. J. Anim. Vet. Adv., 1: 66 -72.

Adiyodi RT. 1988. Reproduction and development. In Biology of the Land Crabs, Burggren AA, McMahon BR (eds). Cambridge University Press: Cambridge, New York; 139-185.

Adopo KL, Kouassi KL, Wognin AVI, Mondé S, Aka K. 2008. Characterization of the sediments and morphology of the Comoé River mouth (Grand-Bassam, Côte d'Ivoire). Rev. Paralia, 1: 2.1-2.10.

Adopo LK, Romanescu G. 2013. Hydrosedimentary operation and impacts on the estuary environmental of Comoé River at Grand-Bassam (Côte d'Ivoire), Lakes, reservoirs and ponds/Romanian Journal of Limnology, 7(2): 89 -100.

Aguirre WE. 2003. Allometric growth of the sulcus in Cynoscion spp. (Sciaenidae). J. Fish Biol., 63: 1341-1346.

Akin-Oriola G, Anetekhai M, Oliwonirejuaro K. 2005. Morphometric and meristic studies in two Crabs: Cardiosoma armatum and Callinectes pallidus. Turk. J. Fish. Aquat. Sci., 5: 85-89.

Ameyaw-Akumfi C. 1987. Mating in the lagoon crab Cardisoma armatum Herklots. J. Crustac. Biol., 7: 433- 436.

Ameyaw-Akumfi C. 1989. Preliminary observations on seasonal movements of Cardisoma armatum Herklots, 1851. Crustaceana, 57: 223 -224.

Anetekhai MA, Owodeinde FG, Ogbe FG. 1994. Meristic and mophormetric features, Age and growth pattern in Cardosoma armatum (Herklots) from Lagos Lagoon, Nigeria. Nig. J. Sci., 19(1): $12-18$.

Burggren WW, McMahon BR. 1988. Biology of the land crabs: an introduction. In Biology of the Land Crabs, Burggren AA, McMahon BR (eds). Cambridge University Press: Cambridge, New York; $1-5$.

Coasta T, Soares-Gomes A. 2008. Relative growth of the fiddler crab Uca rapax (Smith) (Crustacea: Decapoda: Ocypodidae) in a tropical lagoon (Itaipu), Southeast Brazil. Pan Am. J. Aquat. Sci., 3: $94-100$.

Cuesta JA, Liu HC, Schubart CD. 2002. First zoeal stages of Epigrapsus politus Heller, E. notatus (Heller) and Gecarcoidea lalandii $\mathrm{H}$. Milne-Edwards, with remarks on zoeal morphology of the Gecarcinidae Macleay (Crustacea: Brachyura). J. Nat. Hist., 36: 1671 -1685.

Cuesta JA, Anger K. 2005. Larval morphology and salinity tolerance of a land crab from West Africa, Cardisoma armatum (Brachyura: Grapsoidea: Gecarcinidae). J. Crustac. Biol., 25: 640654.

d'Almeida M-A, Koua HK, Ouattara-Soro SF, 
Fantodji A, Ehouman A, N'Diaye AS. 2014. Caractères généraux et étude histologique du développement embryonnaire du crabe terrestre, cardisoma armatum, herklots, 1851 (decapoda gecarcinidae) de Côte d'Ivoire. Afrique Science, 10(2): 338-355. http://www.afriquescience.info, ISSN 1813-548X.

Daniels SR. 2001. Allometric growth, handedness and morphological variation in Potamonautes warreni (Decapoda, Brachyura, Potamonautidae) with a redescription of the species. Crustaceana, 74: 237-253.

Deekae SN, Abowei JFH. 2010. Macrobrachium Macrobrachion (Herklots, 1851) Length-Weight Relationship and Fulton's Condition Factor in Luubara creek, Ogoni Land, Niger Delta, Nigeria. Int. J. Anim. Vet. Adv., 2: 155-162.

Durand J-R, Guiral D. 1994. Hydroclimat et hydrochimie. In Environnements et Ressources Aquatiques de Côte d'Ivoire, les Milieux Lagunaires, (tome II ). Durand J-R, Dufour P, Guiral D, Zabi SG (ed). ORSTOM - IRD: Paris; 56 -90.

Elegbede IO, Fashina-Bombata HA. 2013. Proximate and Mineral Compositions of Common Crab Species [Callinectes pallidus and Cardisoma armatum] of Badagry Creek, Nigeria. Poult. Fish Wildl. Sci., 2(1): 1-5. DOI: http://dx.doi.org/10.4172/21559910.1000164.

Evoy WH, Fourtner CR.1973. Nervous control of walking in the crab Cardisoma guanhumi. III. Proprioceptive influences on intra- and intersegmental coordination. J. Comp. Physiol., 83A: 303 -318.

FAO. 2004. Informations sur l'aménagement des pêches dans la république de Côte d'Ivoire. http://www.fao.org/fi/oldsite/ FCP/fr/CIV/body.htm.

Foale S. 1999. Local ecological knowledge and biology of the land crab Cardisoma hirtipes (Decapoda: Gecarcinidae) at
West Nggela, Solomon Islands. Pacif. Sci., 53: 37-49.

Gilchrist SL. 1988. Appendix: Natural histories of selected terrestrial crabs. In Biology of the Land Crabs, Burggren AA, McMahon BR (eds). Cambridge University Press: Cambridge, New York; 382-390.

Godinho AL. 1997. Weight-length relationship and condition of the characiform Triportheus guentheri. Environ. Biol. Fish., 50: 319 -330.

Greenaway P. 1989. Sodium balance and adaptation to fresh water in the amphibious crab Cardisoma hirtipes. Physiol. Zool., 62: 630- 653.

Hartnoll RG. 1982. Growth. In The biology of Crustacea. Embryology, Morphology and Genetics (vol. 2). Bliss DE, Abele LG (eds). Academic Press: New York; 116 119.

Hartnoll RG. 2001. Growth in Crustacea twenty years on. Hydrobiologia, 449: 111-122.

Hartnol RG, MacKintosh T, Pelembre TJ. 2006. Johngarthia lagostoma (H. Milne Edwards, 1837) on Ascension Island: a very isolated land crab population. Crustaceana, 79: 197 -215.

Hartnoll RG, Broderick AC, Godley BJ, Saunders KE. 2009. Population structure of the land crab Johngarthia lagostoma on Ascension Island. J. Crustac. Biol., 29: $57-61$.

Hauhouot C. 2002. Les problèmes de l'aménagement de l'estuaire du fleuve Comoe à Grand- Bassam. Les Cahiers d'Outre-Mer, 219: 307-324.

Hosteler ME, Mazotti FJ, Taylor AK. 1991. Blue land crab (Cardiosoma guanhumi). University of Florida Extension Paper WEC 30, p. 2.

Huxley JS, Tessir G. 1936. Terminology of relative growth. Nature, 137: 780-781.

Jones RE, Petrell RJ, Pauly D. 1999. Using modified length - weight relationships to assess the condition of fishes. Aquacult. Eng., 20: 261-276. 
Koné YJM, Abril G, Kouadio KN, Delille B, Borges AV. 2009. Seasonal variability of Carbon dioxide in the Rivers and Lagoons of Ivory Coast (West Africa). Estuar. Coast., 32: 246-260.

Lawal-Are AO, Kusemiju K. 2000. Size composition, growth pattern and feeding habits of the blue crab, Callinectes amnicola (De Rocheburne) in the Badagry Lagoon. J. Sci. Res. Dev., 5: 169-176.

Lawal-Are AO, Bilewu B, 2009. The biology of the smooth swim crab, Portunus validus (Herklots) off Lagos coast, Nigeria. Eur J. Sci. Res., 30: 402-408.

Le Cren D, 1951. The length-weight relationship and seasonal cycle in gonad weight and conditions in the perch Perca fluviatilis. J. Anim. Ecol., 20: 201-219.

López-Victoria M, Werding B. 2008. Ecology of the endemic land crab Johngarthia malpilensis (Decapoda: Brachyura: Gecarcinidae), a poorly known Species from the tropical Eastern Pacific. Pacif. Sci., 62(4): 483-493.

Manning RB, Holthuis LB. 1981. West Africa Brachyuran Crabs (Crustacea: Decapoda). Smithson. Contr. Zool., 306: 1-379.

Miyasaka H, Genkai-Kato M, Goda Y, Omari K. 2007. Length-weight relationships of two varunid crab species, Helice tridens and Chasmagnathus convexus in Japan. Limnology, 8: 81-83.

Mohapatra A, Mohanty RK, Mohanty SK, Dey S. 2010. Carapace width and weight relationships, condition factor, relative condition factor and gonado-somatic index (GSI) of mud crabs (Scylla spp.) from Chilika lagoon, India. Indian $J$. Mar. Sci., 39: 120-127.

Omotoso OT. 2005. Chemical composition and nutritive significance of the land crab, Cardisoma armatum (Decapoda). Afri. J. Appl. Zool. Environ. Biol., 7: 68 72.
Pinheiro MAA, Fiscarelli AG. 2009. Lengthweight Relationship and Condition factor of the Mangrove Crab Ucides cordatus (Linnaeus, 1763) (Crustacea, Brachyura, Ucididae). Braz. Arch. Biol. Technol., 52: 397-406.

DOI: http://dx.doi.org/10.1590/S151689132009000200017.

Richter H, Lückstädt C, Focken UL, Becker K. 2000. An improved procedure to assess fish condition on the basis of length-weight relationships. Arch. Fish. Mar. Res., 48: 226-235.

Rodríguez A. 1997. Biologia del langostino Penaeus kerathurus (Forskal, 1775) del golfo de Cádiz. III. Biometría, edad y crecimiento. Investigaciones Pesqueras, 51: 23-38.

SAS, 2008. SAS Online Doc. Version 9.1.3. SAS Institue Inc, Cary, NC 2002.

Skinner LF, Siviero FN, Coutinho R. 2007. Comparative growth of the intertidal barnacle Tetraclita stalactifera (Thoracica: Tetraclitidae) in sites influenced by upwelling and tropical conditions at the Cabo Frio region. Brazil. Rev. Biol. Trop., 55: 71-78.

Schneider W. 1992. FAO species Identification Guide. Guide to the marine commercial resources of the Gulf of Guinea. FAO, RAFR / FI / 90 / 2. Rome, p. 268.

Valiela I, Babiec DF, Atherton W, Seitzinger S, Krebs C. 1974. Some consequences of sexual dimorphism feeding in male and female crabs, Uca Pugnax (Smith). Biol. Bull., 147: 652 - 660.

Vannini MA, Cannicci S, Berti R, Innocenti G. 003. Cardisoma carnifex (Brachyura): where have all the babies gone? $J$. Crustac. Biol., 23: 55 - 59.

Wolcott TG. 1988. Ecology. In Biology of the Land Crabs, Burggren AA, McMahon BR (eds). Cambridge University Press: Cambridge, New York; 55-96. 